\title{
Types and Functions of English Code Switching Employed in Arab Soap Operas at Jordanian and Nile Drama TVs
}

\author{
Mohammad Al-Shehab*, Abd Al-Rhman Al-Okour, \\ English Department, Jadara University, Jordan \\ Corresponding Author: Mohammad Al-Shehab, E-mail: jordan_1948@yahoo.com
}

\begin{tabular}{l} 
ARTICLE INFO \\
\hline Article history \\
Received: July 16, 2018 \\
Accepted: : October 12, 2018 \\
Published: December 01, 2018 \\
Volume: 7 Issue: 7 \\
Advance access: October 2018 \\
Special Issue on Language \& \\
Literature
\end{tabular}

Conflicts of interest: None Funding: None

\begin{abstract}
This study aims at analyzing the functions and types of English Code Switching (CS) used by the Actors in Jordan and Nile drama TVs. To allow data collection and to achieve the purpose of the study, the researchers observed 90 hours of Arab series "Musalsalat" in Jordan and Nile Drama TVs in the month of Ramadan 2017. The collected data represented by the Arabic sentences that included English CS, they were analyzed and investigated quantitatively and qualitatively. Quantitatively, percentages and ranks were computed for the functions and types of English CS, and qualitatively, the researchers analyzed the data based on Discourse Analysis (DA) principles. The results showed that the use of intra-sentential switching was more dominant than intersentential switching. It also showed that the use of interjection function was more common than other functions. Finally, the study was concluded with some recommendations and suggestions for future researches.
\end{abstract}

Key words: English Code-switching, Bilingual, Arab Actors, Jadara University

\section{INTRODUCTION}

As one of the pioneering scholars, Auer (1984) points out that Bilingualism is the ability of an individual or the members of a community to use two languages effectively. Bhatia and Ritchie (2013) continue Auer's idea by saying that Bilingualism is the speaker's ability to use two languages fluently. In the same line, Auer (1998) says that Diglossia is a situation in which two distinct varieties of a language are spoken within the same speech community, on other words; it is a use of two dialects of the same language in the community. Auer (1998) argues that it is the control of using two languages, and Bilinguals have a tendency to use Code Switching (CS) when they talk to others who are able to understand their first and second language. Thus, Bhatia and Ritchie (2013) say that people generally become bilingual because they need it in their daily lives, and they simplify their claim by saying that bilinguals are not necessarily perfectly fluent in their languages. In the same line of research, Cook (2002) states, CS is the phenomenon which happens when bilinguals switch between two common languages that they are sharing in the middle of a conversation. Hence, Cook continues that this switch may occur between or within sentences, involving phrases, words, or even parts of words. In the same vein, Muysken (2000) discusses his idea, he says that CS sometimes appears between the turns or switches of speakers in the conversation, or sometimes between utterances within a single turn, as well as it may occur within a single utterance. On the other side, Bokamba (1988) says that CS is the embedding of several linguistic units such as affixes and clauses from two separate (sub) systems within the same sentence or speech event. Other scientists explain the use of CS, e.g., Coulmas (2005) claims that CS is frequently used in bilingual communities or by bilingual speakers, they use certain codes to transfer their intentions to each other. Coulmas emphasizes, CS is considered one of the explicit and communicative strategies in conversations.

\section{Definition of Code Switching (CS)}

To know more about this phenomenon, it is an argent request to define CS. The first person who tried to define the phenomenon of CS is Gemperz in 1977 by pointing out that $\mathrm{CS}$ is "the juxtaposition of passages of speech belonging to two different grammatical systems or subsystems, within the same exchange" (p.1). Gemperz (1982), on the other hand, defines CS as "the combination within the same speech belonging to two different grammatical systems of subsystems" (p. 59). Bokamba (1989) illustrates CS as the process of using words, phrases, and sentences from two grammatical different language systems within the same utterances.

Skiba (1997) states that CS is the alternation between two codes (languages or dialects) in the conversation between people. Skiba (1997) says that CS could occur in several forms, including alteration of words, phrases, and clauses. Describing the nature of CS, Romaine (2000) says that CS is a natural phenomenon occurring in language. This phenom- 
enon could be developed and expanded when the speakers learn more than one language and feel that they have the competence to use it suitably and correctly in different communication contexts.

In the same vein of talk, Poplack (2004) explains the term $\mathrm{CS}$ as the shifting between two different linguistic systems in the conversation. Auer (1999) defined CS as "a language alternation phenomenon"(p. 309). It seems that Auer and Poplack agree with the definition of CS as a phenomenon of alternation language. Emphasizing this fact, their idea is underpinned by Holmes (2013) who defines CS as it is to move from one code (language) to another during a conversation. Also, in the same research step, Harjunpää and Mäkilähde (2016) indicate that CS is the use of more than one language within an exchange of utterances.

Another definition is set up by Rasul (2013), he defines $\mathrm{CS}$ as switching forth and back between languages during the same utterance. At the same vein, Nordquist (2017) defines $\mathrm{CS}$ as the process of moving back and forth between two languages or between two dialects of the same language. $\mathrm{He}$ adds that $\mathrm{CS}$ occurs in conversation more than in writing.

\section{Functions of Code Switching}

There are lots of functions of CS, and these functions are not fully studied in the sociolinguistic field. Salih (1997) suggests that CS serves a variety of functions such as: Gap-Filling Function, Brevity, Prestige, Knowledge of Foreign Languages, Sarcasm, Expressive Function, Directive Function, Euphemism, and Pedagogical Function. On the other side, Appel and Muysken (2006) suggest six functions of CS: Referential function, Expressive function, Directive function, Poetic function, Meta linguistic function, and Emphatic function.

On the other hand, several researchers dedicated their work to deal with the phenomenon of CS. For instance, (Norrick, 2009; Abu Mathkour, 2004; Koziol, 2000; Gumperz, 1982). They point out that CS serves a variety of functions such as: personalization, reiteration, designation, substitution, emphasis, clarification, objectification, aggravating messages, interjections, parenthesis, quotation, and topic shift. This study has come to deal with quotation, personalization, reiteration, interjections, message qualification, and the researcher takes into his consideration the soap operas of the Jordanian and Nile Drama TVs.

\section{Types of CSs}

Describing the types of CS, Blom and Gumperz (1972) and Auer (1984) indicate that there are two types of CS such as are the situational CS and metaphorical CS. The situational $\mathrm{CS}$ is the process that occurs when bilingual or multilingual speakers tend to use different languages or language varieties that are compatible with the situation. The metaphorical CS is a process occurs when bilingual or multilingual speaker intends to send special message and that message agrees with the situation. In the same line of research, Chan (2005) suggests that situational CS can describe how bilingual or multilingual speakers switch according to their social positions, whereas the use of metaphorical CS is to call the attention of the hearer. Differently, Poplack (1981) suggests three types of CS which represented by tag-switching, inter-sentential switching, and intra-sentential switching. The researchers follow Poplack's types, but they deal only with two types; inter-sentential switching, and intra-sentential switching, as Myers-Scotton (1993b), who suggests two types of switches: inter-sentential or intra-sentential and these types of switches can be derived from utterances.

\section{Inter-sentential switching}

Muysken (1995) says that an inter-sentential CS the switch occurs at the clause or sentence boundary where a clause or a sentence is in one language and the later is in a different language. Myers-Scotton (1993) also points out that the speaker in an inter-sentential switching uses one language in a sentence and turns into another language in the same sentence. These examples are cited from this study:

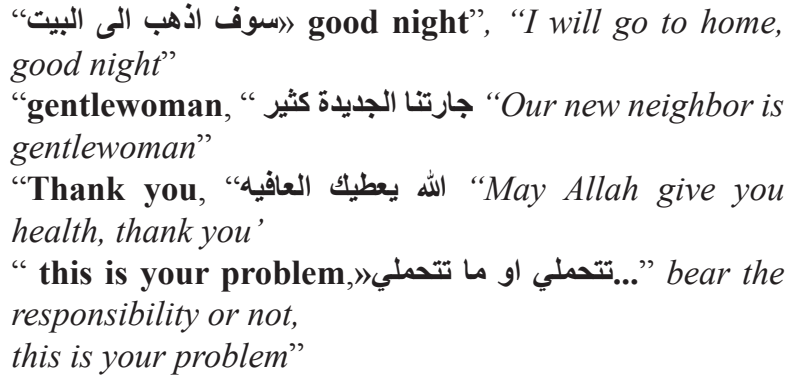

\section{Intra-sentential switching}

Muysken (1995) identifies intra-sentential switching as the switching which occurs within the clause or sentence boundary. Myers-Scotton (1993) indicates that a speaker uses two totally different languages inside the same sentence. Poblack (1980) says that switching happens at the clause level, phrase level, or at word level, specifically in the middle of a sentence.

Many studies were written dealing with the functions of CS. e.g., (Abu Mathkour, 2004; Zerg, 2006; AlShehab, 2014). Abu Mathkour (2004) examines the functions of English CS in conversations by Jordanians in Jordan Television (JTV). The sample consists of 33 Jordanians (18 females, 15 males). Abu Mathkour uses the recording tapes for six hours. The findings pointed out five functions of CS that are realized in conversations in JTV, they are interjection; reiteration, message qualification and Personification vs. objectification. Another study was done by Zerg (2006), who investigated several functions of CS used by Libyan Arabic speakers. She uses code alternation to indicate to code-switching in her study. Zerg collected her data from sixty subjects, they are thirty-six females and twenty-four males. She used thirty hours of spontaneous recording and observation notes to collect her data. AlShehab (2014) investigated CSs applied by translation students at Jadara University in Jordan. He analyzed the types and functions of CS used by the sample, which consists of 100 translation students who were selected randomly from the Department of Translation at the same university. 
On the other side, a lot of international studies were done dealing with the functions of CS, e.g., (Koziol, 2000; David, 2003). Koziol (2000) examined the function of CS between Spanish and English in the United States. She used a relaxed method of observation, and she collected several samples from 38 people during 16-hour period. She observed that her results agree with other researchers' studies. The results of the study also showed that there were differences of using $\mathrm{CS}$ regarding gender for the benefit of women. She set up different functions such as personalization, reiteration, designation, substitution, emphasis, clarification, objectification, aggravating messages, interjections, parenthesis, quotation, and topic shift. David (2003) investigated the role and functions of CS used by key personnel in a courtroom, e.g., lawyers, judges, and witnesses in Malaysian courtrooms. She used handwritten transcripts for 12 hours in lower courts and 12 hours of transcripts in Sessions and high Court because both audio and video recordings were not allowed. She noted that many of the older lawyers were more comfortable and proficient in English, while the younger lawyers were more comfortable in Malay because the instruction plays an important role in this case.

Turnbull (2011) examined the functions of English-Spanish CS between two bilingual sisters. The findings of his study indicated to find more than one function for CS. For instance, they used CS to quote someone and to make a new identity. In this case, they were increasing the illocutionary force of command when they used switching to English. Furthermore, they used it in complaining when they commanded someone, and to insert Spanish names to keep their identity.

Koban (2012) discussed the patterns of intra-sentential and inter-sentential code-switching in the speech between Turkish and English bilinguals' adults in New York City. The sample in this study was 20 bilingual speakers who lived in the US. The results of this study showed that intra-sentential CS happened more than inter-sentential CS. In sum, this study exposed a number of academic studies that dealt with functions of CS, e.g., (Abu Mathkour, 2004; Zerg, 2006; AlShehab, 2014; David (2003). Most of these studies focused on the educational context except the study of David (2003) which focused on the Courtroom, and the study of Zerg's (2006) which looked for Code alternation among Libyan Arab speakers. Only two studies dealt with CS's types, e.g., Koban (2012) and AlShehab's (2014).

\section{Problem of the Study}

Despite the countless studies done that dealing with the functions and types of English CS in Jordan, there is a lack in studying them in media, which is the place of learning and understanding new scientific terms. Because no one can ignore the role of media in developing English terms and expressions, it is necessary to study CS's functions and types in media, which is nearly has been ignored, and unfortunately, a gap-as a research problem-is being occurred. At the same vein of research and to resolve the problem, the study is planned to investigate the types and functions of English CS at the Arab media. Actually, to link the gap, and to reconcile between the media and the academic context, the researchers distinguish the urgent need to address this issue to furnish knowledge for the scientific research. To study the functions and types of English CS used by the Arab media, the study adopts the following two questions:

1. What are the functions of English CS employed by the actors in Arab series at Jordan and Nile TV drama?

2. What are the types of English CS employed in Arab series in Jordan and Nile TV Drama?

\section{Objectives of the Study}

The study aims at analyzing the types of English CS those are used by Arab Actors at the Arab media in Jordan and Nile drama TVs. It that also aims at investigating the functions of CS that are utilized by Arab Actors.

\section{Significance of the Study}

The significance of the current study emerged from its subject; it gets a better understanding of the linguistic functions and types of English CS in the Arab media. The study could help those who are concerned with this field, and could provide some guidelines and ideas to write about this phenomenon in future research.

\section{Limitations of the Study}

The study is limited to 90 series with 90 hours to be observed in the month of Ramadan in 2017. It is also limited to Jordan and Nile Drama TVs only.

\section{METHODOLOGY}

\section{Population and the Sample of the Study}

The population of the study includes all Arab series "Musalsalat" in Jordan and Nile Drama TVs in the month of Ramadan in the year 2017. They are about 15 soap operas (series) with 450 episodes. The sample is chosen conveniently, and the researchers observe 90 series with $20 \%$ of the total population. It is about 90 hour's observation.

\section{Data Collection}

To achieve the aim of the study, and to get more information of $\mathrm{CS}$, the researchers used a direct observation as a tool to collect data. The researchers observed the dialogues used by Arab Actors of the selected sample of Arab series at Jordan and Nile drama TVs. Consequently, YouTube had been observed for nearly 90 hours, and then the researchers wrote the expressions of English CS in a booklet, followed by setting up a list of CSs, which was analyzed and investigated by the researchers according to English CS's types and functions.

\section{Data Analysis}

To analyze the collected data, the study employed Discourse Analysis (DA) method as a qualitative approach. The researchers listened to YouTube and recorded the sentenc- 
es used by Arab actors that include English CSs, and then the recorded sentences were set up into a booklet. At the same vein of research, the researchers tabulated their data and classified them according to CS's functions and types (Appendix A shows 15 from 200 analyzed sentences). Additionally, quantitative approach was applied, e.g., the percentages and the ranks were computed for the types and functions of English CS used by actors.

\section{RESULTS AND DISCUSSIONS}

\section{The Results Related to the First Question: What are the Functions of English CS Employed by the Actors in Arab Series at Jordan and Nile Drama TVs?}

For answering the first question, the researchers analyzed the data by identifying the functions of English CS in the recorded dialogues relying on a number of experts in this field such as Abu Mathkour (2004), who classified them into five: Interjection, Message qualification, Personification, Quotation, and Reiteration. Then, the frequencies, percentages, and the ranks of these functions were computed as shown in table 1.

From the table above, the functions could be arranged in descending order; Interjection with $47 \%$, Message qualification with $27.5 \%$, Reiteration with $15.5 \%$, Personification with $8.5 \%$, and Quotation with $1.5 \%$.

\section{Interjection}

From table (1), the function that is called interjection ranked the first. The table shows that its rate of recurrence is 94 with a percentage of $47.5 \%$. Norrick (2009) defines Interjection as a word, phrase, or sound that is used to express an emotion, such as happiness, anger, an excitement, or a surprise. Gumperz (1982) explains interjection as the function which serves as either an interjection or sentence filler. For more examples in table 2 as follows:

As we noted in the above table, the speaker expresses her emotion, which is happiness about the man's act of marrying his beloved one by using English word bravo that is called CS. The second example of English CS is when the wife formulates her feelings by using an English phrase good surprise, which is used here to express the emotion of speaking. This is indicated by Norrick (2009) who says interjection is related to happiness, anger, an excitement, or a surprise. This saying is underpinned by Abu Mathkour (2004) who also indicates that Jordanian speakers frequently use English words

Table 1. The percentages and the ranks of functions of code switching used by actors

\begin{tabular}{lccc}
\hline Functions & Frequencies & \% & Rank \\
\hline Interjection & 94 & 47 & 1 \\
Personification & 17 & 8.5 & 4 \\
Message qualification & 55 & 27.5 & 2 \\
Quotation & 3 & 1.5 & 5 \\
Reiteration & 31 & 15.5 & 3 \\
All & 200 & $100 \%$ & \\
\hline
\end{tabular}

as sentence fillers in their spoken Arabic, e.g.,; OK, yes/no, please, thank you, already, maybe, hi, bye. For example, the third CS is represented by the English word please in the sentence as word filler which works as interjection. Table 1 shows that interjection is the highest function that occurs in Jordan and Nile TVs drama. This result agrees with Abu Mathkour (2004) findings.

\section{Message qualification}

The second rank is for the function Message qualification; the recurrence of this function is 55 with $28 \%$. It occurs, as Gumperz (1982) says, when the speaker tends to add information to a specific thing that has already been said in another language. In other words, in an introduced topic, the speaker tends to switch to a familiar language between the participants to clarify or to specify the message. For examples as in table 3 :

It could be seen in the first sentence, Masa and her sister talk about their neighbor, she tends to switch to English CS clinic to identify where she has gone to be more familiar. Another example, the second sentence, the speaker tends to explain the English CS nerd by giving the hearer more clarification about the message by using the familiar language (Arabic). The speaker switches to English, then he returns to Arabic to clarify and give more information about the message. Another example in sentence three, the speaker clarifies the English word infection by using Arabic word " "ع sure that a hearer gets the message clearly and it is understood.

\section{Reiteration}

The third rank is for the function Reiteration, it has achieved $15.5 \%$ with 31 frequencies, it occurs when a speaker repeats a message or part of it by the same speaker in another language to amplify or emphasize the meaning of the sentence. For examples in table 4 . In the first sentence, the speaker repeats the phrase sit down twice to emphasize his purpose of the message. In the second example, the speaker switches to another language and repeats the English CS weekend many times to strengthen the situation of his speech. Another example is set in the fourth sentence, the speaker tends to use a medical English term Cancer instead of the Arabic term SaraTan. This process helps the speaker to clarify the purpose of the message for the listener.

In the previous examples the speaker switches to English to clarify the purpose of the message and to be sure that message is understood by listeners. Gumperz (1982) explains reiteration as; when a speaker repeats a message or a part of it in another language to emphasize, this repetition may be occurred either literally or in another modified form such as the above English CSs. David (2003) says that the technical items are popular examples that are related to reiteration function in order to clarify the purpose of his talks.

\section{Personification}

The fourth function is Personification, it has 17 recurrences with $7.5 \%$, it occurs when a speaker wants to express his/her 
Table 2. Examples of 'interjection' function of code switching

\begin{tabular}{|c|c|c|}
\hline No. & Kind of sentence & The sentences \\
\hline \multirow[t]{3}{*}{1} & Arabic sentence & بنت تقول لصديقتها : bravo" عليه, تزوج البنت اللي بحبها “ \\
\hline & Transliteration & ......................... "bravo 3alaih tazwaj albint "illi bihibha" \\
\hline & Translation & A girl says to her friend: bravo, he married his beloved girl \\
\hline \multirow[t]{3}{*}{2} & Arabic sentence & زوجة تخبر زوجها: ” بدي اعل good surprise اللك“" \\
\hline & Transliteration & ........................ "bdi a3mal "ilak good surprise ", \\
\hline & Translation & A wife tells her husband: "I want to make a good surprise for you" \\
\hline \multirow[t]{3}{*}{3} & Arabic sentence & ارجوكي اقبليها مني please خالد يقول لام فوزي: "و لاء سألتني عن الهدية \\
\hline & Transliteration & ......................... : "wala' saa'latni 3 an alhadyeh, please, arjuki eqbaleeha mini”" \\
\hline & Translation & Khalid says to Fawzi's mother: walaa' asked me about the gift, please accept it from me. \\
\hline
\end{tabular}

Table 3. Examples of 'message qualification' function of English code switching

\begin{tabular}{|c|c|c|}
\hline No. & Kind of sentence & The sentences \\
\hline \multirow[t]{3}{*}{1} & Arabic sentence & “، العيادة... clinic مسا بتقول لاختها: ”بلا ما اكذب روحت لعنده على ال \\
\hline & Transliteration & .................. "bala ma akathib ruhit 13indoh 3ala al clinic al3iyadeh" \\
\hline & Translation & Masa says to her sister: I do not lie; I went to him in the clinic....clinic \\
\hline \multirow[t]{3}{*}{2} & Arabic sentence & ”يعني, دائما الأولى على الددرسة nerd بابا سمر طالبة،" \\
\hline & Transliteration & Baba Samar Talibit nerd, ya3ni, daiimaan ala'ula 3la almadrasah" \\
\hline & Translation & Dad, Samar is a nerd student, which means that she is always the first in the school. \\
\hline \multirow[t]{3}{*}{3} & Arabic sentence & "و هاي العادة لازم نخلص منه infection التقبيل ظاهره شائعة بالمجتمع الاردني و هي مصدر عدوى، \\
\hline & Transliteration & $\begin{array}{l}\text { "altaqbeel Zahirah shaa'3ieah bil mojtama3 alurduni waheya maSdar 3adwa, infection, lazim nakhlus } \\
\text { minha" }\end{array}$ \\
\hline & Translation & $\begin{array}{l}\text { The phenomenon of kissing is common in the Jordanian society, and it is the source of infection, this } \\
\text { habit should be stopped. }\end{array}$ \\
\hline
\end{tabular}

Table 4. Examples of 'reiteration' function of English code switching

\begin{tabular}{|c|c|c|}
\hline No. & Kind of sentence & The sentences \\
\hline \multirow[t]{3}{*}{1} & Arabic sentence & اجلسي" اهلا وسهلا \\
\hline & Transliteration & "Ijlesi, sit down "ahlaan wasahlan" \\
\hline & Translation & A Man says to a girl: set down set down, you are welcome. \\
\hline \multirow[t]{3}{*}{2} & Arabic sentence & weekend” وجعتي لي ر اسي بنهاية الاسبوع نهاية الاسبوع"، \\
\hline & Transliteration & "waja3ti li rasi bi nihayat al osbou3 weekend weekend" \\
\hline & Translation & You caused me a headache at the weekend weekend \\
\hline \multirow[t]{3}{*}{3} & Arabic sentence & "هذه مشكنتلك انا اتاخرت this is your problem سامي يقول لمرتن: "تتحملي او ما تتحملي \\
\hline & Transliteration & "tatahamali a'w ma tatahamali this is your problem hathehi mushkilatik 'ana atakhart" \\
\hline & Translation & Sami says to his wife: if $u$ bear or not this is your problem this is your problem, I am late. \\
\hline \multirow[t]{3}{*}{4} & Arabic sentence & "منتشر بالأمعاء Cancer الدكتور يخبر امه: ” حالته صعبه كثير ال \\
\hline & Transliteration & .............."haltuh sa3bah kTheer al Cancer muntashir bi alam3aa" \\
\hline & Translation & $\begin{array}{l}\text { A doctor tells his mother that his condition is very difficult because of the Cancer is spread in his } \\
\text { bowel. }\end{array}$ \\
\hline
\end{tabular}

personal opinions. Examples are shown in table 5, the table shows the example that includes English CS as an expression with three words I like to face, while the second example indicates one word as an English CS, it is cute. The speaker expresses his/her personal opinion by using the English word cute to emphasize or get attention to their opinion from others.

\section{Quotation}

The fifth function is Quotation, it has achieved 1.5\%, it occurs in many cases as either as reported speech or as direct quotations. This function of $\mathrm{CS}$ is accomplished when a speaker conveys a message from one language to another. For more data, table 6 shows two examples as bellow: 
Table 5. Examples of 'personification' function of English code switching

\begin{tabular}{|c|c|c|}
\hline No. & Kind of sentence & The sentences \\
\hline 1 & Arabic sentence & " صديقه تقول لصديقها : I like to face" الصناكل وجها لوجاه, ما بحب اهرب منهم \\
\hline \multirow{5}{*}{2} & Transliteration & ............... "I like to face almashakil wajhan liwajeh, ma bihib ahrob minhum" \\
\hline & Translation & A friend says to her friend: I like to face problems face to face not to escape facing them. \\
\hline & Arabic sentence & " و أنا كثير مغرم بها cute ر امي يقول لعمه: ” بنتك كثير \\
\hline & Transliteration & .............."bintak kTheer cute wa a'na kTheer mughram biha" \\
\hline & Translation & Ramy says to his uncle, your daughter is very cute; I'm fond of her very much. \\
\hline
\end{tabular}

Table 6. Examples of 'quotation' function of English code switching

\begin{tabular}{|c|c|c|}
\hline No. & Kind of sentence & The sentences \\
\hline \multirow[t]{3}{*}{1} & Arabic sentence & to be or not to be " رجل يشجع ابنه: ” ادرس على امتحان بكره \\
\hline & Transliteration & ........: "udrus 3ala imtihan bukrah: to be or not to be" \\
\hline & Translation & A man encourages his son: study for tomorrow exam, to be or not to be. \\
\hline \multirow[t]{3}{*}{2} & Arabic Sentence & black sheep" بنت تقول لابيها: ” يا بابا انت شخص ظالم بتعاملني كأني \\
\hline & Transliteration & .................: "ya baba anta shakhS Zalim, bet3amilni ka’ni black sheep" \\
\hline & Translation & A girl says to her father: O' daddy, you are unjust person, you are treating me as a black sheep. \\
\hline
\end{tabular}

In the first sentence, the speaker used a quotation as an English CS to be or not to be from Hamlet play, which is written by William Shakespeare. Hamlet said this quotation when he contemplated death and suicide on the stage. Then, he asks himself this question, which is to be or not to be. Here the speaker encourages his son by using this quotation which is quoted from Hamlet play. Another example below, the English expression black sheep is used here as a quotation to signify to her unjust treating by her father.

From the above results and discussions, it could be seen that the interjection occurs frequently more than other functions, it has got the first rank with $47.5 \%$. That agrees with Abu Mathkour (2004) result in his thesis. The function of Message qualification occurs less than CS than the function of interjection with the percentage of $28 \%$. Bader (1995) says that Jordanians frequently tend to use English to show the sign of the prestige by using the English language especially in greeting and thanks or in apologize. The results show that the Reiteration function is less in its occurrence than Message qualification; it has got the third rank with $15.5 \%$. The next function of CS is personification, which has achieved the fourth rank with $7.5 \%$. The less occurrence of CS is for the function quotation with $1.5 \%$, this is on the one hand. On the other hand, David (2003) indicates that the personification function occurs in daily conversation more than in televised conversations.

During this study, it is observed that English CS is may be used largely due to a number of factors, e.g., the first one the development of media through Arab world, and the second is the increase percentage of educated people, especially in Jordan.

\section{The results related to the second question: What are the types of English CS employed in Arab series at Jordan and Nile Drama TVs?}

Qualitatively, the researchers observed and recorded the dialogues between the actors in Jordan and Nile TV Drama. The
Table 7. Frequencies, percentage and ranks of css types used by actors in nile and jordanian drama tvs

\begin{tabular}{lccc}
\hline Types & Frequencies & \% & Rank \\
\hline Inter-sentential & 89 & 44.5 & 2 \\
Intra-sentential & 111 & 55.5 & 1 \\
All & 200 & $100 \%$ & \\
\hline
\end{tabular}

researchers investigated and analyzed the data to identify the types of CS in these dialogues relying on experts and their knowledge in this field. Quantitatively, as previously said, the researchers recorded 200 sentences that contain English CSs. They found 89 sentences as inter-sentential type and 111 ones as intra- sentential type as shown in table 7 .

As seen above intra-sentential has got the first rank with $55.5 \%$, while inter- sentential has got the second rank with $44.5 \%$.

\section{Inter-sentential CS}

Inter-sentential CSs as Muysken (1995) says, is the switch occurs at the clause or sentence boundary where a clause or sentence is in one language and the later is in a different language.

In table 8 , the first sentence, the speaker starts with the English expression please my love, and then he ends with Arabic talk in order to emphasize the specific idea. On the other hand, in the second sentence, the speaker starts with the Arabic language and ends with the English language please as a CS. The speaker puts the English word please at the beginning of the conversation, and she continues her speech in Arabic, he changes to another language in order to confirm a particular point. At the same line, the third example, she starts with Arabic and continues her question with English language parking in order to emphasize a particular idea also. The fourth sentence starts with Arabic and ends 
with English CS clinic. The last sentence ends with English expression the new look, the husband questioned her wife to see his new look to attract her attention to him.

\section{Intra-sentential CS}

The second type of CS is intra-sentential, it has got $55.5 \%$. It occurs within the boundary of a sentence as a speaker inserts English word in his/her sentence where he/she uses two totally different languages inside the same sentence.

Table 9 shows four sentences as examples of English types of CS. The first and the fifth examples demonstrate the insertion of the English CS sorry, school as words into Arabic sentences; here the speaker uses two languages inside one sentence. The second sentence expresses the insertion of
English sentence two cups of coffee please as an English CS phrase in the middle of Arabic sentence. The speaker uses two different languages in the same sentence, where he starts with Arabic language then he changes to English and he continues with Arabic.

The third sentence shows the expression oh my god at the middle of the sentence surrounded by Arabic language. At the same vein of research, the English expression please, my darling is also set up at the middle of the Arabic sentence

The results indicate that the intra-sentential CSs are spread frequently more than inter-sentential in both TVs drama. This result agrees with Koban (2013) and AlShehab (2014) findings. AlShehab (2014) finds that the common pattern of intra-sentential consists of only single words or short phrases from target language. Koban's (2013) study

Table 8. Examples of inter-sentential types of English code switching

\begin{tabular}{|c|c|c|}
\hline No. & Kind of sentence & The sentences \\
\hline \multirow[t]{3}{*}{1} & Arabic Sentence & "اهم شي في حياتي ما تكون مزعوج "فناة لصديقها: please my love" \\
\hline & Transliteration & ............."please, my love, aham shi fi hayati ma takun maz3uj" \\
\hline & Translation & A girl to her friend: please, my love, the most important thing in my life is not to be upset. \\
\hline \multirow[t]{3}{*}{2} & Arabic Sentence & please” سكرنيره تقول لثخص : " انتظره هون \\
\hline & Transliteration & 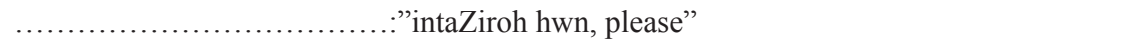 \\
\hline & Translation & A secretary says to someone: wait him here, please. \\
\hline \multirow[t]{3}{*}{3} & Arabic Sentence & parking..” موظفة تسأل المدير : "ليش انت و اقف بـال \\
\hline & Transliteration & $\ldots \ldots \ldots \ldots \ldots \ldots \ldots \ldots \ldots \ldots . .$. "laish anta waqif bil parking" \\
\hline & Translation & An employee asks the manager: why are you standing in the parking? \\
\hline \multirow[t]{3}{*}{4} & Arabic Sentence & clinic" طبيب يقول للسكرتيرة: "هلا انا ما بجلس وحدي ب \\
\hline & Transliteration & ....................."Hala ana ma bajlis wahadi fil clinic" \\
\hline & Translation & A doctor says to the secretary: "now, I will not sit alone in the clinic". \\
\hline \multirow[t]{3}{*}{5} & Arabic Sentence & the new look" زوج يقول لمرته: "كيف بتشوفي \\
\hline & Transliteration & .........................."kaif bitshufi the new look" \\
\hline & Translation & A husband says to his wife: "how do you see the new look". \\
\hline
\end{tabular}

Table 9. Examples of inter-sentential types of English code switching

\begin{tabular}{|c|c|c|}
\hline No. & Kind of sentence & The sentences \\
\hline \multirow[t]{3}{*}{1} & Arabic Sentence & "حبيبي ما كان قصدي شي sorry و الله،" \\
\hline & Transliteration & Wallah sorry habibi ma kan qasdi shei \\
\hline & Translation & Sorry my love, I did not mean anything. o'God, \\
\hline \multirow[t]{3}{*}{2} & Arabic Sentence & "عند عيادة الدكتور ريان two cups of coffee please السكرتيرة تقول للموظف: "با احمد \\
\hline & Transliteration & "ya Ahmad two cups of coffee please 3inda 3iyadat alduktur Rayan \\
\hline & Translation & A secretary says to the employee: Ahmad, please two cup of coffee to Dr. Rayan clinic. \\
\hline \multirow[t]{3}{*}{3} & Arabic Sentence & "هيك بشعر اننا في حرب oh my god رجل يقول لبنته: "في حرب هون \\
\hline & Transliteration & ................: Fi harb hown, oh my god, haik bash3or inana fi harb” "“ \\
\hline & Translation & A man says to his daughter: is it a war here, oh my god, I feel that we are in a war. \\
\hline \multirow[t]{3}{*}{4} & Arabic Sentence & “ ، لا تكذبي please, my darling بدي اسئلك سو ال بس، \\
\hline & Transliteration & “ “bidi 'as'alak su'al bas please, my darling la takathibi \\
\hline & Translation & I want to ask you just a question, please, my darling, don't lie \\
\hline \multirow[t]{3}{*}{5} & Arabic Sentence & "مار راح تفيد حدا school الين تقول لصديقتها: ”نزولي على ال \\
\hline & Transliteration & nozoli 3la il school ma rah tafeed hada" \\
\hline & Translation & Alyin says to her friend: my going to the school will not benefit anybody \\
\hline
\end{tabular}


has shown that there is a relationship between language proficiency of participants and intra-sentential CS. They indicate that inter-sentential occurs at sentential boundaries, where the first clause is in one language and the following clause is in another language. This study has shown that bilingual speakers who dominant in both Arabic and English use intra-sentential more than inter-sentential. This study meets Alshehab's (2014) study in dealing with the types of English CSs.

\section{CONCLUSION}

To be concluded, this study aimed at analyzing the types and the functions of CS at Jordan and Nile Drama TVs. For achieving its objectives, the researchers selected all Arab series "Musalsalat" in Jordan and Nile drama TVs during the month of Ramadan (2017). The researchers observed 90 hours of series with $20 \%$ of the total population. Consequently, there were 200 Arabic sentences included English CSs were extracted from the Arab actors' talks. For analyzing data, DA method was used to take out the types and the functions of English CSs employed by Arab actors. The findings revealed that the actors in the Arab series used both types of English CSs that are intra-sentential and inter-sentential for benefit of intra-sentential CS. The study revealed that English CS had five functions in media, e.g. interjection, message qualification, personification, quotation, and reiteration. It also showed that the interjection occurred more frequently than other functions. The less frequent was for the function of quotation, it achieved three frequencies with $1.5 \%$. The results cannot be generalized to the all Arab media as the number of sentences is too small in comparative with the vast media series and data.

Based in the results of this study, it is recommended for studying the reasons and attitude toward using the phenomenon of CS at Arab drama from various perspectives. Likewise, it is suggested for studying the effect of social variable, e.g. age, gender, ethnicity, economic status, and the level of education on using English or Arabic CS. Moreover, the study suggested studying CS phenomenon from syntactic and pragmatic perspective among the Jordanian people and students. Lastly, it is hoped that this study could present a bit contribution to social research and knowledge.

\section{REFERENCES}

Abdel Jalil, S. (2009). Grammatical perspectives on code-switching. Jurnal ReVEL, 7(13), 1-11.

Abu Mathkour, H. (2004). Arabic with English: Code switching in Jordanian Arabic. social sciences and humanities 3 , pp:1-12.

AlShehab, M. (2009). Issues in translating military terms and texts between English and Arabic. Unpublished Ph.D thesis: University of Science and Technology, Malaysia.

AlShehab, M. (2014). The English Code Switching Expressions used by Translation Students during their Daily Translation at Jadara University in Jordan. European journal of English language studies, 2 (1),1-18
Appel, R., \& Muysken, P. (1987). Language contact and bilingualism. Amsterdam University Press.

Auer, P. (1984). Bilingual Conversation. Amsterdam: Benjamins Publishing Co.

(1998).Code switching in conversation: Language, interaction and identity. New York, NY: Routledge

. (1999). From codeswitching via language mixing to fused lects: Toward a dynamic typology of bilingual speech. International Journal of Bilingualism 3: 309-332

Bhatia, T., \& Ritchie, W. (2013). The handbook of bilingualism and multilingualism. Oxford: Wiley-Blackwell

Blom, J. P., \& Gumperz J. (1972). Social meaing in linguistic structure: Code-switching in Norway. In J. Gumperz, \& D. Hymes (Eds.), Directions in sociolinguistics (pp.407-434). New York: Holt, Rinehart and Winston.

Bokamba, E. G. (1989). Are there syntactic constraints on code-mixing?. World Englishes, 8(3), 277-292.7

Bokamba, E. G. (1988). Code-mixing, language variation, and linguistic theory: Evidence from Bantu languages. Lingua, 71(1), 21-62.

Chan, B. (2005). Conversational code-switching and Relevance Theory, Paper presented at the $9^{\text {th }}$ Conference of International Pragmatics Association (IPrA9), Riva Del Garda, Italy.

Cook, V (ed.). (2002). Portraits of the L2 User. Clevedon: Multilingual Matters.

Coulmas, F. (2005). Changing language regimes in globalizing environments. International Journal of the Sociology of Language, 2005(175-176), 3-15.

David, M. K. (2003). Role and function of code-Switching in Malaysian courtrooms. Multilingua: Journal of Cross-Cultural and Inter language Communication, 22(1), 5- 20.

Gumperz, J, \& Hymes, D. (Eds). 1972. Directions in Sociolinguistics. New York: Holt, Reinhart, Winston

Gumperz, J. (1982). Discourse Strategies. New York, NY: Cambridge University Press.

Holmes, J. (2013). An introduction to sociolinguistics $\left(4^{\text {th }}\right.$ Ed). NewYork,NY: Routledge.

Koban, D. (2012). Intra-sentential and Inter-sentential Code-switching by Turkish English Bilinguals in New York City, US. Science Direct Procedia - Social and Behavioral Sciences, 70, 1174-1179.

Koziol, J. M. (2000). Code-Switching between Spanish and English in Contemporary American Society. Master thesis. St Mary's College of Maryland.

Muysken, P. (1995). Code-switching and grammatical theory. In L. Milroy, \& P. Muysken (Eds.), One Speaker, Two Languages: Crossdisciplinary Perspectives on Code-switching. 177-197, New York: Cambridge University Press.

Muysken, P. (2000). Bilingual speech: A typology of code-mixing. Cambridge, England: Cambridge University Press.

Myers-Scotton, C. (1993). Dueling Languages: Grammatical Structure in Code-switching. Oxford: Clarendon Press. 
Myers-Scotton, C. (1993b). Social Motivation for code switching: Evidence from Africa, Oxford: Claredon Press.

Norrick, N.R.(2009). Interjections as Pragmatic Markers. Journals of Pragmatics, 4, 866- 891

Poplack, S. (1980). Sometimes I'll start a sentence in Spanish y termino enespan"ol: Towards a typology of code-switching. Linguistics, 18, 581-618.

Poplack, S. (2004) Code---Switching. In Ammon, U.,N. Dittmar, K. J Mattheier, and P. Trudgill (eds), Sociolinguistics. An International Handbook of the Science of Language and Society ( $2^{\text {nd }}$ ed). Berlin: Walter de Gruyter. 589---596.

Rasul, Sarwet (2013). Borrowing and code mixing in Pakistani children ${ }^{\text {ee }}$ magazines: Practices and functions. Journal of Pakistan Studies, 5(2), 46-74.
Romaine, Suzanne. (2000). Language in society: An introduction to sociolinguistics. New York: University Press.

Salih, Mahmud (1997). Sociolinguistic functions of code- mixing in Jordanian Arabic. Ajman University of Science and Technology Journal, 3(1), 70-88.

Skiba, R. (1997). Code switching as a countenance of language interference. The internet TESL journal, 3(10), $1-6$.

Turnbull, A. (2011). Code- switching in Spanish English Bilingual Speech: The Case of Two Recent Immigrants of Mexican Descent.Retrieved Nov. 17, 2016 from World Wide Web: http//www.tc.columbia.edu/tesolal web journal.

Zerg, H. (2006). Code alternation among Libyan Arab speakers. Unpublished M.A Dissertation. Yarmouk University,Irbid, Jordan.

\section{APPENDIXS}

Appendix A. Analysis of English CSs used by actors in Jordanian and Nile drama

\begin{tabular}{|c|c|c|c|}
\hline No. & Sentence & Function & Type \\
\hline 1. & حبيبي ما كان قصدي شي sorry و الله & Interjection & Intra-sentential \\
\hline 2. & goodnight صديق بحكي لصديقته & Interjection & Inter-sentential \\
\hline 3. & و جارنا الجديد كثير gentleman & Message qualification & Inter-sentential \\
\hline 4. & وما حد برد private number رقمي اعطيته لحد تاني لانه بدقلي & Mmessage qualification & Intra-sentential \\
\hline 5. & I ر اح ادقلك I promise & $\begin{array}{l}\text { First one is Personification } \\
\text { The Second one is Reiteration }\end{array}$ & $\begin{array}{l}\text { the first switching is Intra } \\
\text { but the second is Inter }\end{array}$ \\
\hline 6. & اذا بدي suspense مسا بتحكي لريان بدك الصر احه حياتي كلها & Interjection & Intra-sentential \\
\hline 7. & عليها CV بشركه كنت مقدم interview بابا بكره عندي & $\begin{array}{l}\text { The First switching is Interjection but } \\
\text { the second is Message qualification }\end{array}$ & Intra-sentential \\
\hline 8. & دكتور بحكي لصديقته عن امه انها للاسف معها cancer & Reiteration & Inter-sentential \\
\hline 9. & مسا بتحكي لاختها بلا ما اكزب روحت لعنده على clinic & Message qualification & Inter-sentential \\
\hline 10. & الي حضر تكو طالبينه بحاحه لخبره post هلا & Interjection & Intra-sentential \\
\hline 11. & لا تكزبي علي please بدي اسئلك سو ال بس & Interjection & Intra-sentential \\
\hline 12. & صديق بحكي لصديقته انه بده يعمل كل شي على ذوقها فبتحكي deal & Interjection & Inter-sentential \\
\hline 13. & هنالك مثل يقول: like father like son & Quotation & Intra-sentential \\
\hline 14. & 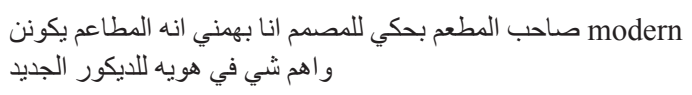 & Message qualification & Intra-sentential \\
\hline 15. & 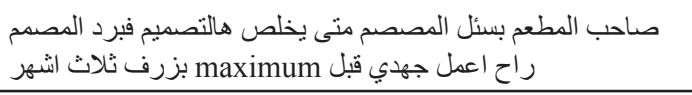 & Message qualification & Intra-sentential \\
\hline
\end{tabular}




\begin{tabular}{|c|c|}
\hline الحرف العربي & الحرف الانجليزي ـ الفتحة والكسرة والضمة \\
\hline 1 & a aa, i, o \\
\hline ب & b ba, bi, bo \\
\hline$ت$ & $\mathrm{t}$ ta, ti, to \\
\hline$ث$ & Th Tha, Thi, Tho \\
\hline ج & j ja, ji , jo \\
\hline$\tau$ & Н Ha, Hi, Ho \\
\hline$\dot{\tau}$ & kh kha, khi, kho \\
\hline د & $\mathrm{d}$ da, di, do \\
\hline$\dot{~}$ & th tha, thi, tho \\
\hline J & r ra ri, ro \\
\hline j & z za, zi, zo \\
\hline 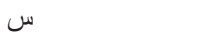 & s sa, si, so \\
\hline 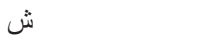 & sh sha, shi, sho \\
\hline ص & $\mathrm{S} \mathrm{Sa}, \mathrm{Si}$, So \\
\hline 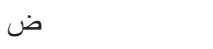 & dh dha, dhi, dho \\
\hline b & T Ta, Ti, To \\
\hline ظ & $\mathrm{Z}$ Za, Zi, Zo \\
\hline$\varepsilon$ & 3 3a, 3i, 3o \\
\hline$\dot{\varepsilon}$ & gh gha, ghi, gho \\
\hline ف & $\mathrm{ffa}, \mathrm{fi}, \mathrm{fo}$ \\
\hline ق & q qa, qi, qo \\
\hline ك & k ka, ki, ko \\
\hline 」 & 1 la, li, lo \\
\hline s & $\mathrm{m} \mathrm{ma}, \mathrm{mi}, \mathrm{mo}$ \\
\hline ن & n na, ni, no \\
\hline 。 & h ha, hi, ho \\
\hline g & w wa, wi, wo \\
\hline ى & y ya, yi, yo \\
\hline i & $a^{\prime}$ \\
\hline ع عاه نطوبرم عات & $\mathrm{t}-\mathrm{h}$ \\
\hline ى & y ya, yi, yo \\
\hline i & $a^{\prime}$ \\
\hline عاه ذظوبرم عات ة & ht - \\
\hline
\end{tabular}

